УДК 331.101 .32

Болквадзе Наталія, кандидат економічних наук, доцент, Тернопільський національний економічний університет, кафедра міжнародних економічних відносин, м. Тернопіль; ORCID ID 0000-0002-1253-5892, e-mail: polikevychnata@gmail.com

Гетьман Тетяна, магістрант,

Тернопільський національний економічний університет, кафедра міжнародних економічних відносин, м. Тернопіль; ORCID ID 0000-0003-0154-6550, e-mail: tatianahetman5@gmail.com

https://doi.org/10.29038/2411-4014-2020-02-72-82

\title{
СУЧАСНІ МЕТОДИ МОТИВАЦІЇ ПЕРСОНАЛУ ІТ-КОМПАНІЙ
}

У статті розкрито новітні методи мотивації персоналу, а також розглянуто роль стимулів в процесі мотивації праці. Охарактеризовано теорію очікувань В. Врума та наведено правила, які покликані допомогти підвищити мотивацію співробітників компанії. Проаналізовано динаміку росту кількості IT-спеціалістів в Україні та їх географічну приналежність. Здійснено опитування працівників IT сфери в м. Тернопіль для виявлення найголовніших факторів, що впливають на їх мотивацію. Підтверджено, що мотивація орієнтована лише на грошове заохочення, не є достатньою. Згідно з проведеним опитуванням виявлено, що професійний ріст та комфортний психологічний клімат відіграють не менш важливу роль у мотивації ІТ-фахівців, а ніж матеріальні стимули.

Ключові слова: мотивація, персонал, методи мотивації, теорія очікувань, потреби працівників, стимулювання.

Болквадзе Наталья, кандидат экономических наук, доцент, Тернопольский национальный экономический университет, кафедра международных экономических отношений,

г. Тернополь

Гетман Татьяна, магистрант,

Тернопольский национальный экономический университет, кафедра международных экономических отношений,

г. Тернополь

\section{СОВРЕМЕННЫЕ МЕТОДЫ МОТИВАЦИИ ПЕРСОНАЛА ИТ-КОМПАНИЙ}

В статье раскрыто новейшие методы мотивации персонала, а также рассмотрено роль стимулов в процессе мотивации труда. Охарактеризовано теорию ожиданий В. Врума и приведены правила, которые призваны помочь повысить мотивацию сотрудников компании. Проанализирована динамика роста количества ИТ-специалистов в Украине и их географическую принадлежность. Осуществлен опрос работников ИТ-сферы в г. Тернополь для выявления главных факторов влияющих на их мотивацию. Подтверждено, что мотивация ориентирована только на денежное поощрение, не является достаточным. Согласно проведенному опросу выявлено, что профессиональный рост и комфортный психологический климат играют не менее важную роль в мотивации ИТ-специалистов, нежели материальные стимулы.

Ключевые слова: мотивация, персонал, методы мотивации, теория ожиданий, потребности работников, стимулирование. 


\section{Bolkvadze Nataliia, \\ PhD in Economics, Assistant Professor, \\ Ternopil National Economic University, \\ Department of International Economic Relationship, \\ Ternopil \\ Hetman Tatiana, \\ Master student, \\ Ternopil National Economic University, \\ Department of International Economic Relationship, \\ Ternopil}

\section{MODERN METHODS OF STAFF MOTIVATION OF IT COMPANIES}

The article describes the newest methods of motivating staff, not focusing solely on material incentives. The role of incentives in the process of work motivation as specific external irritants is considered. In the article, incentives are also considered as levers of influence, which concentrate certain motives of a person. The theory of expectations of V. Vrum, which states that the employee is obliged to have such needs, which can be significantly satisfied with the result of anticipated rewards, is characterized. The rules that are intended to help increase the motivation of the company's employees are outlined. The growth dynamics of the number of IT specialists in Ukraine and their geographical identity are analyzed. It is revealed that geographically Ukraine is divided into five IT hubs (Kyiv, Odesa, Lviv, Dnipro, Kharkiv), which accumulate 75\% of all IT employees in Ukraine. Accordingly, startup projects and the latest developments of the IT-sphere are implemented and based in these hubs. The IT sector employees in Ternopil were interviewed to identify the main factors that influence their motivation. The main age category of employees in IT companies is young people aged 18 to 25 years (68.3\%), and 25 to 45 years (31.7\%). The number of men working in the IT sector is $63.3 \%$ and women $-36.7 \%$, which means that the prevalence of men in the companies surveyed is significant. In our opinion, this situation is explained by the change of priorities in the young generation and the desire of women to develop new professions in the IT field. The largest number of respondents work in companies up to a year, and the least number of employees work at the same company for more than five years, which indicates that the companies have insufficient staff turnover policies. The study confirmed that motivation focused solely on monetary incentives is not sufficient. According to the survey, it was found that professional growth and comfortable psychological climate play no less important role in the motivation of IT professionals than material incentives. Besides, the curiosity of the accomplished tasks, the workplace, stability, free schedule, the ability to work outside the office, the status, and the brand of the company is dramatically important.

Key words: motivation, staff, methods of motivation, theory of expectations, needs of employees, stimulation.

Постановка проблеми. Для вдалого та результативного існування будь-якого виробництва, компанії чи організації, незалежно від послуг та товарів які вона пропонує, потрібні ефективні та кваліфіковані кадри. Якщо компанії вдалося сформувати колектив із надійних працівників, необхідно вагому увагу приділяти їх мотивації. Стимулювання працівників займає одне з головних місць в управлінні персоналом, оскільки таким чином компанії можуть досягати значних результатів у своїй діяльності. I тому, заохотити працівників орієнтуватися на досягнення цілей компанії $\epsilon$ основним завданням управління персоналом.

Незнання основ мотивації персоналу та економія коштів на методах мотивування $є$ головними проблемами компаній, що хочуть підвищити результативність своїх працівників. Найчастіше увага приділяється соціально-психологічним аспектам стимуляції персоналу, що створюють певні умови для здобуття значних результатів виробничо-господарської діяльності, з мінімальними низькими та ризиками.

Аналіз останніх досліджень і публікацій. Проблему мотивації персоналу знайшла своє відображення в наукових дослідженнях як вітчизняних, так і зарубіжних науковців, а саме: В. Врум [11], Ф. Херцберг[12], Д. Макклелланд [13], А. Маслоу [14], О. Бугуцький [16] та інші.

Виділення невирішених раніше частин загальної проблеми. Конкурентоспроможність вітчизняних компанії на ринку залежить від вміння пристосовуватися до внутрішніх та зовнішніх викликів. Одним із ефективних способів внутрішньо підсилити компанію - це залучення 
кваліфікованих працівників, що в свою чергу потребує впровадження вітчизняними компаніями новітніх методів керування персоналом базуючись на досвіді міжнародних фірм.

Виклад основного матеріалу. Фахівці по роботі 3 персоналом, протягом останніх років вивчають, досліджують та пропонують новітні та оригінальні способи стимулювання працівників. Стандартні методи, в основі яких лежали лише грошові винагороди відійшли у минуле, а на заміну їм прийшли сучасні методи, які отримують відголос за допомогою неекономічних шляхів стимулювання [1, с. 200].

На сьогоднішній день, у процесі мотивації праці стимули відіграють значну роль. Стимули - це специфічні зовнішні подразники, яким властива роль «важелів» впливу, які концентрують ті чи інші мотиви людини [5]. Особливість стимулів полягає у тому, що вони запрограмовані виконувати роль «каталізатора» активності працівників, а відповідно спрямованість якої вже буде визначатися внутрішньою мотиваційною структурою особистості. Стимули будуть ефективними та зможуть вплинути на результати діяльності співробітника лише тоді, коли вони здатні викликати реакцію людини до певної ситуації.

Кравчик В.К. [3, с. 12] зазначає, що стимулювання має різні форми, а особливо поширеним є матеріальне стимулювання. У своїй праці «Про сутність маркетингу трудових ресурсів» Кравчик В.К. [3, с. 12] вважає, що «...процесом стимулювання - являється процес використання різних стимулів для мотивування людей...» та варто враховувати ситуацію, коли матеріальне стимулювання буде найбільш оптимальним і не призведе до нівелювання самого стимулу. Таке обмеження є необхідним з огляду на складну та не однозначну систему потреб, пріоритетів, інтересів i цілей працівників. Система мотивування за принципом «батога i пряника» недооцінювала цю особливість людської мотивації. Жодна система керування не буде ефективно функціонувати без створення ефективної мотиваційної моделі, оскільки мотивація спонукує конкретного індивіда і колектив у цілому до досягнення, як особистих так і загальних цілей в організації [3, с. 12].

Варто звернути увагу на теорію очікувань В. Врума [11], що базується на очікуванні певної події. Вона пояснює важливість трьох взаємозв'язків:

- витрати - результати;

- результати - винагорода;

- винагорода - задоволеність винагородою [8].

Послідовники теорії очікувань запевняють, що рівень мотивації працівників пов'язаний від уявлень суб'єктів щодо своїх вмінь до здійснення різного роду задач і одержання бажаної премії. Теорію очікувань можна сформулювати як вчення, що описує залежність мотивації від двох пунктів: скільки б хотіла людина одержати й наскільки реально для неї отримати те, що вона хотіла б отримати, а саме, як багато зусиль вона готова приділити цьому [9].

Таким чином, в теорії очікувань, потреба не є ключовою умовою мотивації людини задля завоювання певної цілі. Процесуальні теорії очікування показують, що поведінка працівників визначається поведінкою:

- начальника, що при відповідних умов покращує роботу співробітника;

- працівника, який упевнений, що за будь-якої ситуації йому буде видана премія;

- співробітника i начальника, які припускають, що при відповідному покращенні якості роботи, він отримає винагороду;

- співробітника, який ототожнює розмір премії із сумою, яка потрібна йому для задоволення потреби [11].

У своїй науковій праці Іванов С.Л. зазначає, що мотивація буде слабнути, якщо люди не відчувають прямого зв'язку між затратними спробами та досягненими результатами. Брак взаємозв'язку може бути спричиненим неправильною самооцінкою робітника, його слабку підготовку чи невідповідне навчання, недостатності прав у працівника до здійснення необхідного завдання [6, с. 22].

Вище зазначене дає нам розуміння, що в теорії очікування виокремлюється потреба у перевазі удосконалення якості праці й впевненості в тому, що це буде відзначено начальником та дасть працівнику змогу насправді задовольнити свою потребу.

Керівництво компанії мусить складати високий, але реалістичний рівень очікувань від результатів працівників і надихати їх, що вони в змозі досягти цих цілей, якщо докладуть певних 
зусиль. Зазвичай, працівники оцінюють свої зусилля базуючись на тому, що очікує від них їхнє керівництво.

Відповідно, спираючись на теорії очікувань можна сказати, що працівник зобов'язаний мати такі потреби, які можуть значною мірою бути задоволені результатом передбачуваних нагород. Також керівник повинний запроваджувати відповідні заохочення, які зможуть задовольнити очікувану потребу працівника. Задля ефективної мотивації менеджер повинен встановити тверде співвідношення між досягнутими результатами та винагородою. Для прикладу, у ряді комерційних установ нагороду виділяють у вигляді визначених товарів, розуміючи, що працівникам вони необхідні.

Загалом, що теорія очікувань В. Врума має свої позитивні та негативні сторони:

Переваги:

- наявність чіткого співвідношення між результатами та нагородою лише за ефективну роботу;

- ретельний контроль за рівнем самооцінки працівників, їх знань та навичок;

- високе, але реалістичне планування рівня результатів підлеглих.

Недоліки:

- неповністю беруться до уваги індивідуальні особливості кожної людини та організації;

- недостатньо досліджені методологічні заходи та технічна сторона використання моделі у реальному житті.

Отже, головна суть, чому модель В. Врума стала значущою серед сучасних моделей трудової мотивації та породила безліч досліджень, на нашу думку полягає в тому, що вона не вдається до спрощень, оскільки змістовні теорії, в свою чергу занадто спрощують та перефразовують мотивацію людини.

Колот А. наводить правила, які покликані допомогти підвищити мотивацію співробітників [2, с. 198]:

1. Несподівані, непередбачувані і нерегулярні заохочення мотивують краще, ніж прогнозовані. Це правило легко пояснити. Часто так виходить, що ті заохочення про які нам відомо і вони регулярні, можуть на підсвідомості людини прирівнюватися до частини заробітної платні, яку вони звикли отримувати в певний день і в фіксованому розмірі.

2. Мотивування приносить результати, тільки коли робітники відчувають визнання свого внеску та володіють заслуженим статусом. Це пояснюється тим, що всі працівники хочуть визнання, a ті, які про це прямо не говорять все одно про це думають і таємно бажають. Це можливо пояснити егоцентричною природою людини. Проте, використання цього правила має деякі негативні наслідки: збільшення конфліктів в колективі, надмірне переоцінювання та/або недооцінювання працівників

3. Наступне правило - позитивне підкріплення результативніше негативного. Метод «негативного підкріплення» - метод зміни небажаної поведінки. Метод полягає в моментальній і неприємній для працівника реакції на його небажану поведінку. Для прикладу: співробітник не справляється з обов'язками, оскільки він працює за себе і за іншу людину, яка захворіла і яку нікому замінити. У відповідь його начальник вкрай різко реагує на негативний результат і позбавляє його премій, виписує штрафи.

4. Робітників необхідно стимулювати за проміжними досягненням, не чекаючи закінчення всього проекту. Отже, позитивно мотивувати співробітника необхідно частіше та відповідно до об'єму виконаної працівником роботи [5].

5. I останнє правило, яке перетинається 3 першим - заохочення повинні застосовуватися якомога швидше після виконаної співробітником роботи. В жодному разі про заохочення не можна забувати, особливо якщо керівник дав обіцянку співробітнику, що його чекає бонус за виконану ним роботу. У цьому правилі $є$ закономірність: чим довше проміжок між успішно виконаною роботою і заохоченням тим менший ефект від даного заохочення.

В даний час в Україні стрімко збільшується кількість IT-компаній, де переважно працює молодь. Така висока кількість працівників зумовлена швидким ростом галузі та отриманням великого доходу в цій сфері. Проте, навіть попри високий рівень заробітної плати, в компаніях зіштовхуються із недостатньою мотивацією персоналу. В свою чергу це призводить до втрати кваліфікованих працівників (перехід до конкурентів) або виїзд за кордон, що є проблемою. 
Найбільший актив українського ринку розробки програмного забезпечення - це велика кількість IT-фахівців. Станом на 1 квартал 2019 року він нараховує понад 184700 фахівців, і прогнозують, що на кінець 2020 року кількість працівників задіяних в IT сфері перевищить 200000 (рис 1). Згідно досліджень [7] приблизно 60\% українських розробників програмного забезпечення зараз працюють в IT компаніях з аутсорсингу.

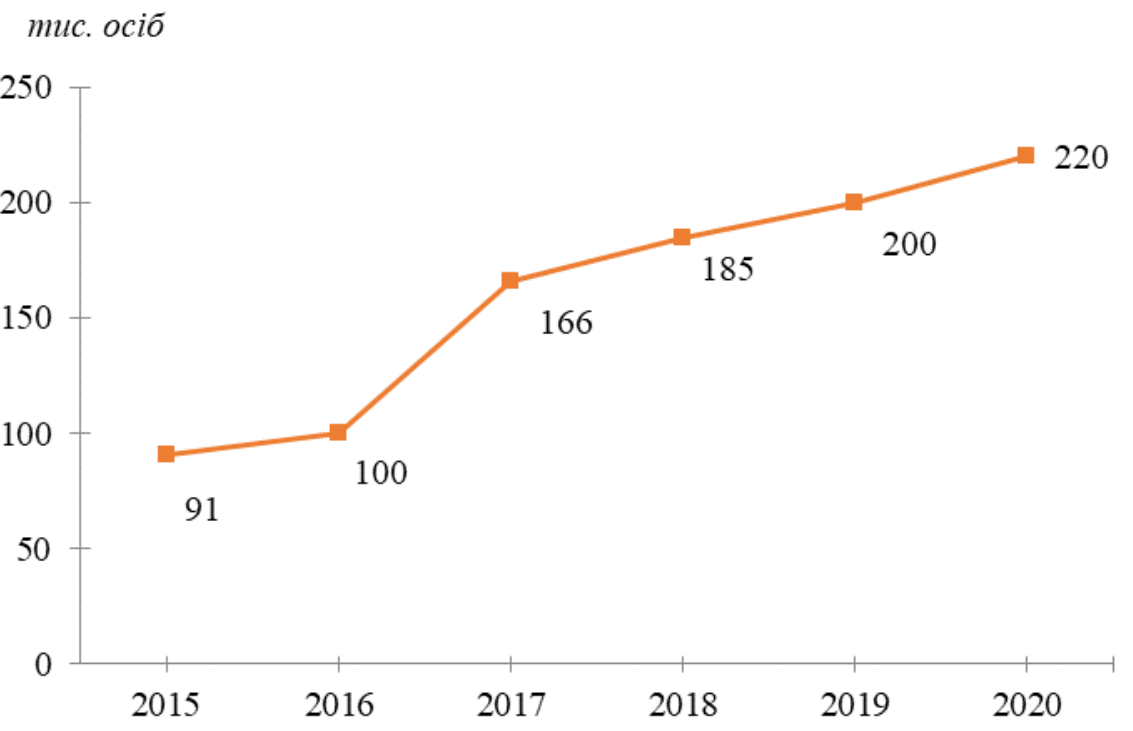

Рис.1. Число ІТ спеціалістів в Україні

Джерело: сформовано автором за даними [7]

Варто зазначити, що окрім високого рівня заробітної плати є ще декілька основних причин такого значного росту кількості IT спеціалістів в Україні, а саме: соціальний статус та престиж, сильна база технологічної освіти, позитивні зміни в законодавстві та податковій політиці стосовно IT сфери, а також географічне положення України.

Головним лідером за кількістю IT-спеціалістів $є$ Київ та київська область. Тут зареєстровано більше ніж 45 тис. працівників (рис. 2). Друге місце займає харківська область де знаходиться близько 22 тис. всіх ІТ-спеціалістів. Третє - львівська область (близько 16 тис. працівників). Дніпропетровська область посідає четверте місце, де $є$ близько 14 тис. IT-спеціалістів. Всі ці міста $\epsilon$ IT хабами, де акумулюються 75\% усіх IT-фахівців України, а також базуються start-up проекти та впроваджуються новітні розробки.

Програмісти в Україні сьогодні - найбільш затребувані працівники. У них практично завжди суттєво зростає заробітна плата, і незалежно від ситуації на ринку праці, вони завжди матимуть робоче місце. Проте й тут трапляються випадки недостатньої мотивації, і тому мотивація персоналу давно стала ключовим чинником працездатності та успішності будь-якої компанії.

Перш за все, важливо приділяти увагу мотивації працівників, які приносять фірмі прямий дохід, а саме менеджери 3 продажу, менеджери проектів і керівники. Далі іде персонал, який займається підтримкою бізнесу, тобто IT-фахівці. Винятком є підприємства, що займаються створенням і продажом IT-товарів і послуг, в яких робота IT-спеціалістів - головне джерело доходу. Тут варто зазначити, що потрібно займатися мотивацією всіх IT-фахівців, не залежно від їх функції в компанії, адже IT-спеціалісти потрібні в кожній компанії і $\epsilon$ важливим структурним і організаційним компонентом. 


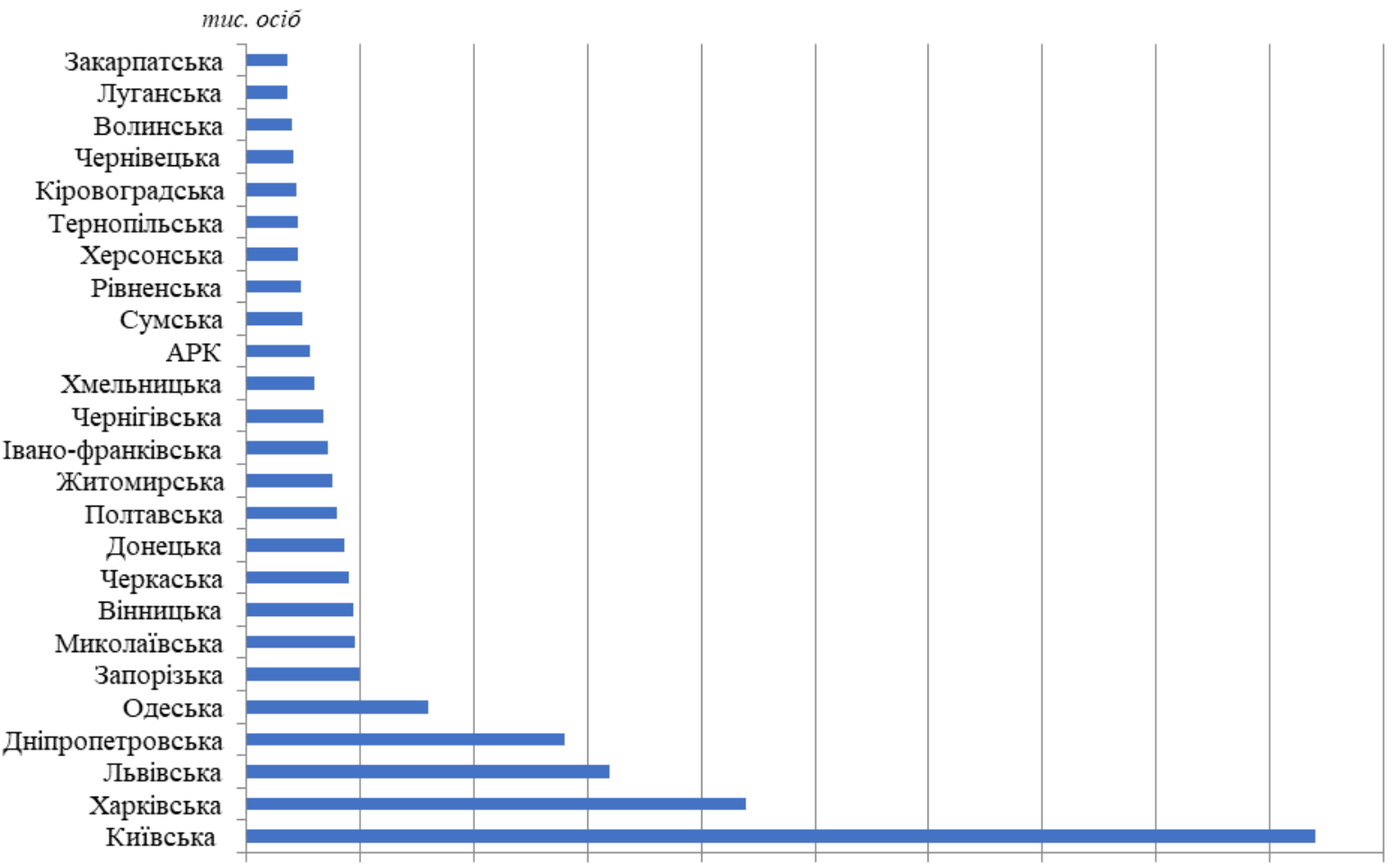

Основно Фิсновно

Рис.2. Кількість IT-спец̧іалістів за областями у 2019 р.

Джерело: сформовано автором за даними [10]

Професійне саморозуміння «айтішників» вагомо розширилося останнім часом. Раніше типовий представник IT-сфери відрізнявся асоціальним мисленням, основним мотиватором був цікавий зміст роботи, а різноманітні дії HR-менеджерів, орієнтовані на ефективну мотивацію персоналу, сприймалися без ентузіазму (типовий коментар: «Bci ці HR-вигадки тільки від роботи відволікають»). Сучасний ІТ-працівник зацікавлений як в матеріальній, так і в нематеріальній мотивації своєї роботи й досить добре обізнаний про власну значущість для компанії [4, с. 45].

Для кращої співпраці та введення ефективної стратегії мотивації, варто проводити аналіз персоналу. Опитування - як метод пізнання соціальних явищ та процесів чудовий спосіб отримання інформації. Саме тому нами було проведено опитування для визначення мотивації персоналу компаній в м. Тернополі, що працюють в IT сфері.

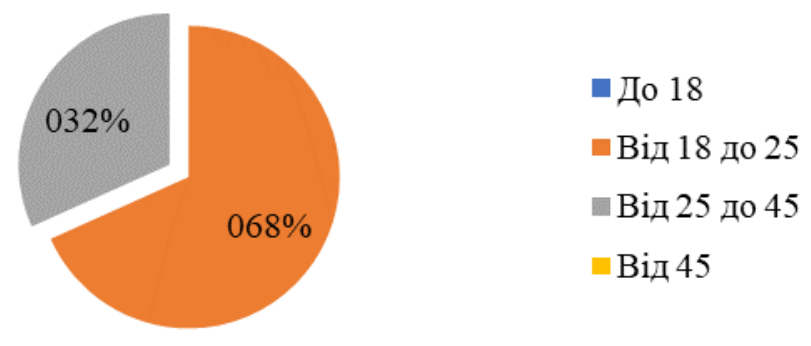

Рис.3. Вікова категорія опитаних

Джерело: сформовано авторами на основі проведеного опитування

Згідно з результатами діаграми (рис.3), основна вікова категорія працюючих в IT компаніях, молодь віком від 18 до 25 років (68,3\%). Респонденти віком від 25 років до 45 років становили $31,7 \%$ опитаних. Як бачимо серед опитуваних немає осіб молодше 18 років та старше 45 років. 


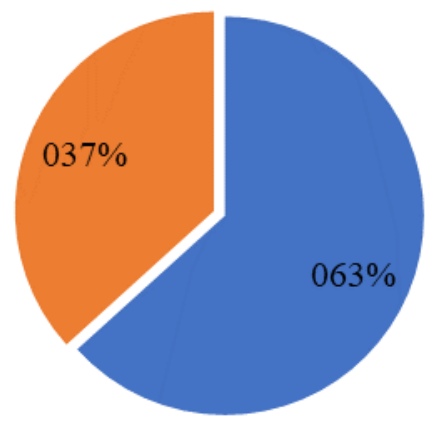

- Чоловік

Жінка

Рис.4. Статева принадлежність респондентів

Джерело: сформовано авторами на основі проведеного опитування

Згідно з рис.4, кількість чоловіків працюючих в IT сфері становить 63,3\%, а жінок - 36,7\%. Ці дані є досить важливі, адже показують, що обидві статі зацікавлені у розвитку своїх здібностей в IT cфepi.

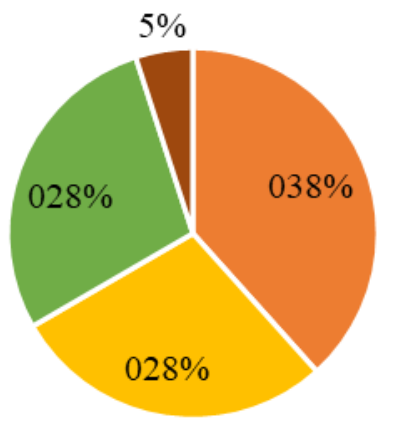

$$
\begin{aligned}
& \text { - До } 1 \text { року } \\
& \text { = 1-2 роки } \\
& \text { = } 3-5 \text { роки } \\
& \text { - } 5 \text { і більше }
\end{aligned}
$$

Рис. 5. Досвід роботи в IT

Джерело: сформовано авторами на основі проведеного опитування

Серед опитаних 38,3\% ІТ-спеціалістів працюють до 1 року. Друге місце займають працівники 3 досвідом роботи 1-2 роки, а третє місце 3-5 років - 28,3\%. Найменша частка належить категорії 5 років і більше - лише 5\%. 3 огляду на ці дані, може зробити висновок про недостатню політику компанії із збереження персоналу та наявну плинність кадрів.

В ході опитування респонденти мали можливість обрати 3 найголовніших фактори, що впливають на їх мотивацію. Як видно із рис.6. серед ІТ-спеціалістів високий дохід та хороший колектив займають найвищі місця зі значенням у 70\%. Далі важливим критерієм $є$ професійний розвиток, що підкреслює важливість для компанії включати в мотиваційну стратегію різні види навчання.

Проаналізуємо обрані категорії у відповідності до відповідей респондентів:

- «Високий дохід». Вважається найлегшою і дієвою мотивацією праці високу заробітну плату. Для працівників в сфері IT, рівень заробітної плати справді займає вагоме місце. Згідно нашого дослідження близько 80\% ІТ-фахівців, які планують змінити свою роботу і займаються активним пошуком нової, на співбесідах головною причиною цього рішення зазначають низький (невідповідний ринку) рівень заробітної плати. Проте, цей спосіб мотивації є досить витратним і не завжди дієвим, а з часом він може стати неефективним, адже високий рівень доходу стає настільки звичним, що не буде впливати на працездатність працівника. 


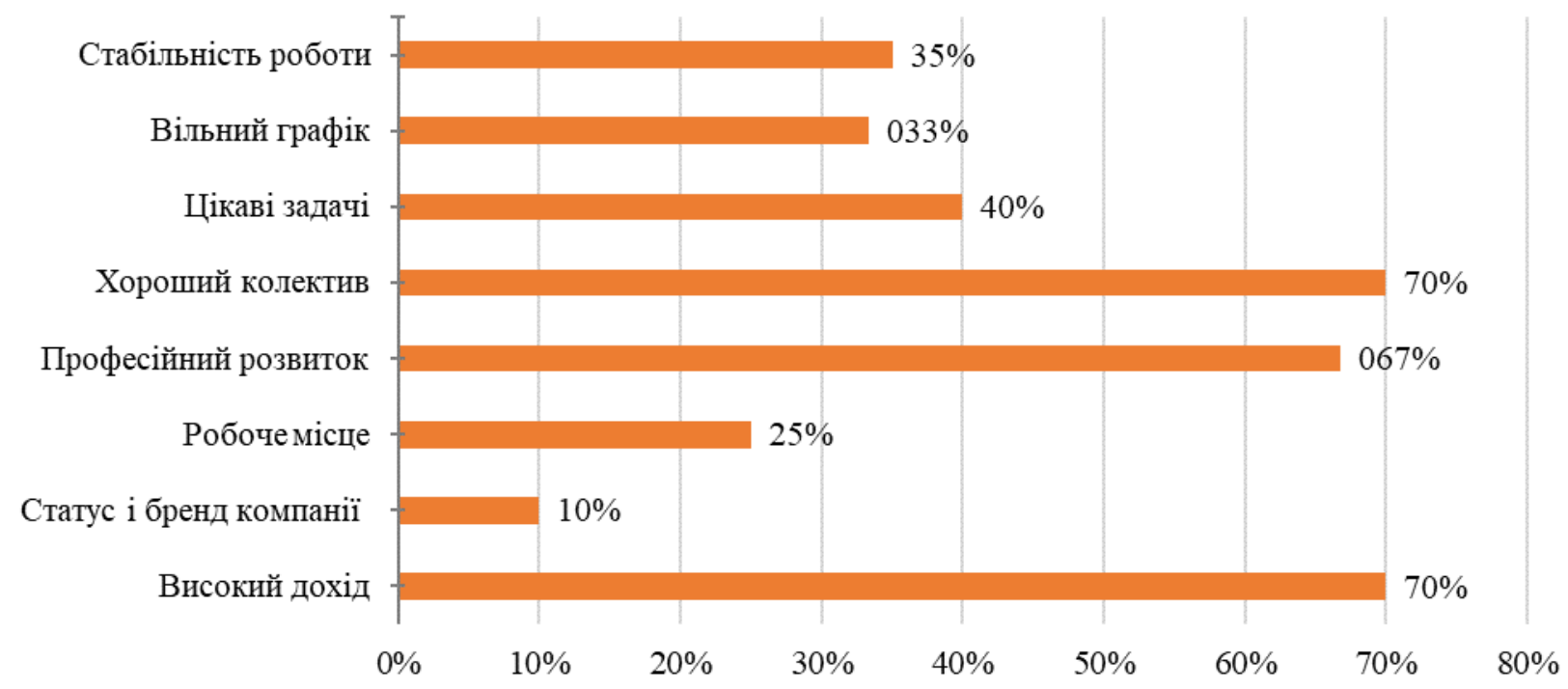

Рис. 6. Фактори, які впливають на комфорт роботи в компанії

Джерело: сформовано авторами на основі проведеного опитування

- «Хороший колектив і керівник». Доброзичливий колектив, лояльний i професійний топ менеджмент - складові психологічного мікроклімату будь-якої компанії. Співробітник, що працює в сприятливих соціальних і психологічних умовах, отримує від роботи більше задоволення, вмотивований на отримання видимого результату як для себе, так і для своєї компанії.

Для IT-спеціаліста в структурі мікроклімату провідну роль відіграє особистість і професіоналізм безпосереднього керівника. Відносини всередині колективу - більш другорядні. При зміні роботи другої за популярністю причиною звільнення після незадовільного рівня зарплати $\epsilon$ догляд шановного керівника і неможливість спрацюватися з новим, некомпетентне керівництво.

- «Професійний розвиток» стоїть на 2 місці - 66,7\%. IT-фахівці надають вагоме значення можливостям постійного особистісного та професійного розвитку. На даний момент працівники ставляться більш лояльно до роботодавців, які повністю або частково оплачують спеціалізоване ITнавчання: отримання професійних сертифікатів, проходження курсів підвищення кваліфікації та ін. В результаті компанія отримує більш професійного співробітника.

- «Цікаві задачі» (40\% респондентів). У рідкісних випадках ІТ-фахівець погодиться виконувати роботу, яка не цікава йому особисто. Звичайно, якщо специфіка роботи IT-служби пов'язана 3 підтримкою існуючої системи, визначеними щоденними рутинними функціями, досить складно заради підвищення мотивації змінити зміст такої роботи. Однак навіть в подібній ситуації можна зробити кроки, які позитивно вплинуть на мотивацію - такі, як розширення існуючих функціональних обов'язків (наприклад, коучинг молодих фахівців), залучення в нові проекти та можливість горизонтальної ротації в ІТ-департаменті.

- «Стабільність роботи» (35\%). Важливість цієї категорії свідчить про формування відданості роботі та впевненості в майбутньому.

- «Вільний графік» (33,3\%). Прихильність до робочого графіка «з 9.00 до 18.00» як єдиного правильного і загальноприйнятого останнім часом переживає свій спад. Вільний графік дедалі більше набуває популярності. Надання можливості обрати для себе графік роботи буде надзвичайною перевагою та мотивацією.

- Робоче місце (25\%). Комфортні умови праці, а саме зручне місце розташування компанії (близькість до центру/ зупинок/метро) і великий, світлий, добре обладнаний офіс займають ажливе місце. Розглядаючи цей мотиватор в розрізі мотиваційної системи IT-фахівця, має сенс виділити деякі його складові такі, як кондиціонер, звукоізоляція, якісні монітори. 
- Статус і бренд компанії (10\%). Важливість працювати у відомій фірмі виявилось не настільки суттєвим в порівнянні із іншими чинниками, що дозволяє стверджувати про зміну в пріоритетах молодого покоління працівників.

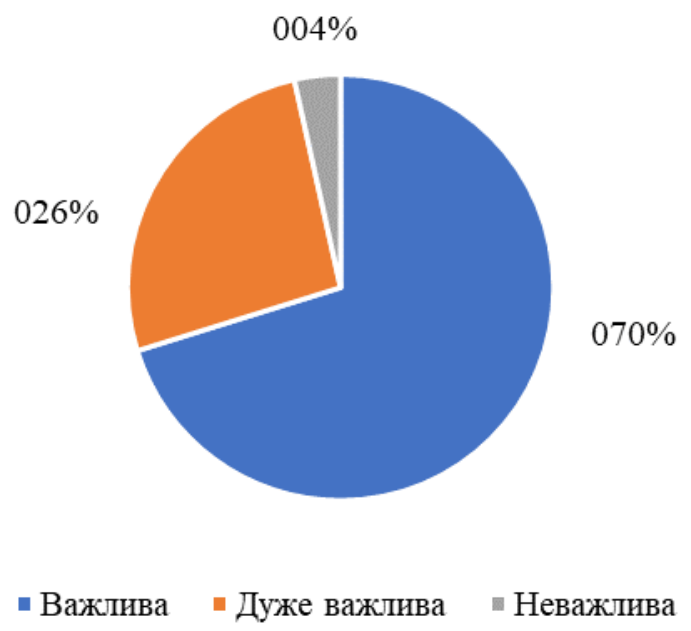

Рис.7. Важсливість грошової мотивації

Джерело: сформовано автором на основі опитування

За результатами опитування (рис. 7) для 70,2\% фінансова мотивації є важливою, для 26,3\% дуже важливою і лише для 3,5\% неважливою.

Відповідно до результатів проведеного опитування можемо зробити висновок, що для підвищення ефективності мотивації працівників IT сфери необхідно враховувати наступні пункти:

- Рівень заробітної плати досить вагомий для IT-спеціалістів, проте для посилення і підтримки рівня мотивації й ефективності роботи працівників $є$ сенс започатковувати бонусну чи преміальну грошову частину;

- Варто мотивувати працівників можливістю отримання професійного росту через проходження ними професійного навчання;

- Комфортний психологічний клімат в компанії допоможе втримати працівників від зміни місця роботи та підвищити зацікавленість в кінцевому результаті спільної проботи.

- Змога обирати графік роботи є вагомим мотиваційним чинником для будь-якого IT-фахівця, що своєю чергою гарантує комфорт i допомагає індивідуальному підходу до оптимізації працездатності співробітника.

Висновки та пропозиції. На успіх та процвітання компанії впливають безліч факторів. Одним 3 них $є$ майстерність мотивації. Для створення ефективної системи мотивації, враховуючи менталітет українського народу, хорошим прикладом є теорія очікувань В. Врума.

Наше дослідження було орієнтоване на IT-компанії що працюють в Україні. Результати анкетування працівників IT-компаній, дозволяють зробити висновок, що мотивація орієнтована лише на грошове заохочення, поступово відходить у минуле. Згідно з нашим опитуванням професійний ріст та комфортний психологічний клімат відіграють не менш важливу роль у задоволенні ITфахівців, а ніж матеріальна мотивація. Додатково слід відзначити, що є досить багато різних факторів які також впливають на кінцевий результат роботи працівника

Система мотивації працівників має бути прозорою та зрозумілою для того, щоб усунути відчуття несправедливості та порівнянь. Кожен співробітник має знати, що за виконання якісної роботи, за ініціативу та нові ідеї, за творчий підхід до рішення завдань, він отримає відповідну винагороду у вигляді премії, знижок, безплатних квитків на участь у конференціях, новітнього обладнання, а також визнання з боку керівника та інших учасників. Отже, нехтування мотиваційним фактором у певній сфері призводить до зниження показників продуктивності праці, якості продукції в кожній конкретній організації чи компанії. 


\section{Джерела та література}

1. Веснин В.Р. Менеджмент персоналу. М.: «Элит-2000». 2015. С. 200

2. Колот А.М. Мотивація, стимулювання й оцінка персоналу. К.: КНЕУ. 2018. С. 198

3. Кравчик В.К. Про сутність маркетингу трудових ресурсів. Вісник Академії праиі і соиіальних відносин Федераиії профспілок Украӥни. 2016. №1. С. 12.

4. Різник В.В., Сучасні тенденції мотивації праці управлінського персоналу. Економічний вісник університету. 2018. №15/1. С. 45.

5. Лукашевич Ю. Стимулювання персоналу як підтримка стратегічного розвитку підприємства. URL: http://www.nbuv.gov.ua/portal/soc gum/Evu/2010_14/Lukashevich\%20UL.pdf. (дата звернення: 16.04.2020)

6. Іванов С.Л. Ролі нематеріальних чинників мотивації праці у формуванні людського капіталу сучасного підприємства в Україні. Наукові праиі НДФІ. 2017. № 5. С. 22-23.

7. Software development in Ukraine: 2019-2020 IT market report. URL: https://www.n-ix.com/softwaredevelopment-in-ukraine-2019-2020-market-report/ (дата звернення: 20.04.2020).

8. Baran B. (2019). Employee Motivation: Expectancy Theory. Management Minutes: Quick Insights Into Behavior at Work. You Tube. URL: http://www.youtube.com/watch?v=0zd5m8V9No0 (дата звернення: 18.04.2020).

9. Isaac R. G., Zerbe W.J., Pitt D.C. Leadership and motivation: The effective application of expectancy theory. Journal of Managerial Issues. 2018. №13(2). P. 212-226.

10.Кількість IT-спеціалістів в Україні зросла на чверть. URL: https://www.epravda.com.ua/news/2019/04/15/647043/ (дата звернення: 19.04.2020).

11.Врум В. Труд и мотивация. 1964. С. 100-120

12. Херцберг Ф., Моснер Б., Блох-Снидерман Б. Мотивация к работе: Пер. с англ. М.: Вершина, 2007. С. 240

13. Макклелланд Д. Мотивация человека. СПб.: Питер. 2007. С. 672 .

14. Маслоу А. Мотивация и личность. 3-е изд. пер. с англ. СПб.: Питер. 2008. С. 352.

15. Колот А.М. Мотивація персоналу. К.: КНЕУ. 2012. С. 397.

16. Богуцький О.А. Фактори розвитку мотивації праці. Економіка АПК. 2005. № 7. С. 46-47.

\section{References}

1. Vesnyn V.R. (2015) Menedzhment personala [HR Management]. Moscow: Elit -2000 [in Russian].

2. Kolot A.M. (2018) Motyvatsiya, stymulyuvannya y otsinka personalu [Motivation, stimulation and evaluation of staff]. Kyiv: KNEU[in Ukrainian].

3. Kravchyk V.K. (2001) Pro sutnist' marketynhu trudovykh resursiv [On the essence of labor marketing]. Visnyk Akademiji praci i socialjnykh vidnosyn Federaciji profspilok Ukrajiny - Bulletin of the Academy of Labor and Social Relations of the Federation of Trade Unions of Ukraine. (Vols. 1), (pp. 18-30) [in Ukrainian].

4. Riznyk V.V. (2010) Suchasni tendentsiyi motyvatsiyi pratsi upravlins'koho personalu [Current trends in the motivation of management staff]. Ekonomichnyj visnyk universytetu - Economic Bulletin of the University. Pereyaslav: Pereyaslav-Khmelnytsky State Pedagogical University named Hryhoriy Skovoroda (Vols. 15/1), (p. 45) [in Ukrainian].

5. Lukashevych J.(2009) Stymulyuvannya personalu yak pidtrymka stratehichnoho rozvytku pidpryyemstva [Stimulating staff to support the strategic development of the enterprise]. Ekonomichnyj visnyk universytetu Economic Bulletin of the University. Retrieved http://ephsheir.phdpu.edu.ua/bitstream/handle/8989898989/461/\%D0\%92\%D0\%B8\%D0\%BF\%D1\%83\%D1\%81\%D0 $\% \mathrm{BA} \% 2014 \% 2 \mathrm{C} \% 202010$. pdf? sequence $=1$ \&isAllowed $=\mathrm{y} \#$ page $=77$ [in Ukrainian].

6. Ivanov S.L (2017) Roli nematerial'nykh chynnykiv motyvatsiyi pratsi u formuvanni lyuds'koho kapitalu suchasnoho pidpryyemstva $\mathrm{v}$ Ukrayini. [The role of intangible factors of labor motivation in the formation of human capital of a modern enterprise in Ukraine]. Naukovi pratsi NDFI - Scientific works of NDFI. (Vols. 5), (pp. 22-23) [in Ukrainian].

7. IT market report (2020) Software development in Ukraine: 2019-2020. Retrieved from: https://www.nix.com/software-development-in-ukraine-2019-2020-market-report/ [in English].

8. Baran B. (2019) Employee Motivation: Expectancy Theory. Management Minutes: Quick Insights Into Behavior at Work. YouTube. Retrieved from http://www.youtube.com/watch?v=0zd5m8V9No0 [in English].

9. Isaac, R. G., Zerbe, W.J., \& Pitt, D. C. (2018) Leadership and motivation: The effective application of expectancy theory. Journal of Managerial Issues. Vol.13(2), pp. 212-226. 
10. Epravda (2019) Kiljkistj IT-specialistiv v Ukrajini zrosla na chvertj [The number of IT specialists in Ukraine has increased by a quarter] Ekonomichna Pravda - Economic Truth. Retrieved from: https://www.epravda.com.ua/news/2019/04/15/647043/

11. Vrum V. (1964) Trud i motivatsiya [Expectation theory] N. Y.

12. Khercbergh F., Mosner B., Blokh Snyderman B. (2007) Motyvacyja k rabote [The Motivation to Work]. Per. s anghl. Moskow: Vershyna [in Russian].

13. Makklelland D. (2007) Motivatsiya cheloveka [Human motivation]. SPb.: Piter [in Russian].

14. Maslou A. (2008) Motivatsiya i lichnost' [Motivation and personality]. 3-e izd. per. s angl. SPb.: Piter [in Russian].

15. Kolot A.M. (2012) Motyvatsiya personal [Staff motivation]. Kyiv: KNEU [in Ukrainian].

16. Boghucjkyj O.A. (2005) Faktory rozvytku motyvatsiyi pratsi [Factors of work motivation development]. Ekonomika APK. (Vol. 7.) (pp. 46-47) [in Ukrainian].

Стаття надійшла до редакції 26.04.2020 р. 